\title{
Hodnotenie vybraných aspektov kurikulárnej reformy na gymnáziách v SR učitel'mi
}

\author{
Petra Fridrichová, Vladimír Poliach \\ Univerzita Mateja Bela, Pedagogická fakulta
}

\begin{abstract}
Abstrakt: $\vee$ rámci predkladaného príspevku sa zameriavame na opis priebehu kurikulárnej reformy na Slovensku vo vzt’ahu k zmenám v gymnáziách. Ďalej analyzujeme vybrané aspekty rozsiahlejšieho exploračného ex post facto výskumu. Dáta sme analyzovali prostredníctvom nástrojov MS Excel a IBM SPSS, hlavne s využitím neparametrických procedúr, čo vyplynulo z povahy distribúcie väčšiny premenných. Výsledky poukazujú na negatívne vnímanie smerovania slovenského školstva po roku 1989, avšak naznačujú, že učitelia očakávajú komplexnú reformu v školstve, ktorá by mala smerovat' $\mathrm{k}$ menším zmenám $\mathrm{v}$ obsahu vzdelávania a k zásadným zmenám $v$ metódach výučby na gymnáziách.
\end{abstract}

Klúčové slová: školská reforma na Slovensku, postoje učitelov, gymnáziá, kurikulárna reforma na gymnáziách

\section{Evaluation of Selected Aspects of Curriculum Reform at Grammar Schools in the Slovak Republic by Their Teachers}

Abstract: This paper focuses on the description of the course of curriculum reform in Slovakia in relation to the changes in secondary grammar schools ("gymnázium"). We offer an analysis of the selected aspects of the broader exploratory ex post facto research. We have analysed the data using MS Excel and IBM SPSS, mainly using nonparametric procedures, which resulted from the nature of the distribution of most variables. The results point to a negative perception of the direction of the Slovak education system by teachers after 1989. Teachers expect a comprehensive reform in education leading to minor changes in the content of education and fundamental changes in the teaching methods at secondary schools.

Keywords: school reform in Slovakia, teachers' attitudes, secondary comprehensive school (gymnázium), curriculum reform at secondary comprehensive schools

Filozofia kreovania nového centrálneho konceptu vzdelávacích politík cez tzv. klúčové kompetencie je determinovaná zmenami potrieb učiacej sa spoločnosti, ktoré vyplývajú z viacerých skutočností: napr. vysoká miera nezamestnanosti, starnutie populácie, rastúca migrácia, marginalizácia niektorých skupín obyvatel'stva, pravdepodobnost' zmeny práce počas produktívneho veku, rastúce tempo technického pokroku. Zdá sa, že doterajší systém edukácie zameraný na vedomosti, neposkytuje $\checkmark$ nových podmienkach dostatočnú prípravu. Pocit nesúladu medzi cielmi a obsahom vzdelávania a požiadavkami spoločnosti je badatel'ný nielen v globálnej rovine (Beck, 2011; Keller \& Tvrdý, 2008; World Economic Forum, 2016), ale čoraz častejšie aj na národnej úrovni a prejavuje sa nekompatibilitou $v$ očakávaniach zamestnávatelov 
114 od absolventov a štátnymi kurikulami (napr. European Commission, 2017; Liptáková, 2017; Vančíková, 2018). Učenie sa, ktoré sa očakáva, znamená formulovanie problémov a hladanie ich vzájomných súvislostí. Jeho hlavnými znakmi sú integrácia, syntéza a rozšírenie horizontu (Rychen \& Salganik, 2003). To vysvetl'uje a zároveň podporuje tendenciu zamerat' sa viac na rozvoj kompetencií, než na odovzdávanie faktografických poznatkov vo výučbe. Tieto a d'alšie dôvody (Kosová \& Porubský 2011a) viedli v roku 2008 k transformáciám v slovenskom školskom systéme, pričom hlavnou zmenou je kompetenčne vystavané kurikulum pre materské, základné aj stredné školy. Avšak, vzhladom na nepripravenost' učitel'ov na zmenu role z užívatelov kurikula na jeho tvorcu (Pavlov, 2013), je priebeh školskej reformy vnímaný ako unikátna skúsenost' (Kosová \& Porubský, 2011b), ktorú je potrebné skúmat' v rovine očakávaní aktérov školstva od reformy a jej skutočných dopadov. Štúdiu priebehu a výsledkov štátnej vzdelávacej politiky na Slovensku sa venuje pozornost' na makroúrovni a mezoúrovni prevažne vo vzt’ahu k základným školám (Kosová \& Porubský, 2011a, 2011b; Porubský et al., 2014, 2016). Skúmaniu priebehu a rezultátov kurikulárnej reformy na gymnáziách na makroúrovni, ani empirickému výskumu implementácie reformy na mezoúrovni, jej prijatia učitel'mi a faktormi, ktoré ovplyvňujú jej úspešnost', sa doposial' nevenovala systematická pozornost'.

$\checkmark$ rámci tejto štúdie sme sa zamerali na prezentovanie výsledkov dotazníkového výskumu zameraného na postoje a názory učitelov gymnázií na Slovensku ku kurikulárnej reforme z roku 2008 a na ich skúsenosti s touto reformou. V úvode príspevku popisujeme spoločenské východiská školskej reformy na Slovensku na úrovni gymnázií a tiež popisujeme vývoj reformy $v$ nasledujúcich rokoch. Tieto atribúty považujeme za kontextuálny rámec ovplyvňujúci prijatie, či neprijatie reformných krokov u učitelov gymnázií. Rozšírenie záberu výskumu zo základných škôl na gymnáziá súvisí predovšetkým s faktom, že proces implementácie reformy v gymnáziách a v základných školách bol rozdielny.

Predkladanú štúdiu chápeme ako vstup do rozsiahlej problematiky implementácie školskej reformy, ovplyvňovanej mnohými faktormi, ktorá si vyžaduje hlbšiu analýzu. Výsledky, ktoré prezentujeme, boli získané $v$ rámci dotazníkového on-line šetrenia v roku 2015 a zameriavajú sa na prijatie kurikulárnej reformy z roku 2008 z pohladu učitelov gymnázií. Zistenia o procesoch iniciácie kurikulárnych zmien na gymnáziách uvádzaných v úvodnej časti štúdie sú výsledkom vlastného výskumu autorov v archíve Štátneho pedagogického ústavu (najmä informácie o národnom projekte Kurikulárna transformácia všeobecno-vzdelávacej zložky stredoškolského vzdelávania v procese prípravy mládeže na trh práce).

\section{Kurikulárna reforma na gymnáziách na Slovensku}

Po roku 1989 sa začali prvé transformačné snahy $v$ slovenskom školstve. Súviseli so zmenou ideológie, vnímania úloh a poslania školy a s celkovým spoločenským uvol'nením. $V$ tomto období vplyvom zahraničných prístupov, ale aj vlastných snáh 
učitelov vznikali rôzne iniciatívy, alternatívy k tradičnému vyučovaniu. Učitelia boli pozitívne naladení na zmeny $v$ školstve a očakávali rýchly nástup školských reforiem, ktoré im vytvoria väčší priestor na realizáciu očakávaných zmien v podobe zvyšovania autonómie škôl a učitel'ov. Hybnou silou pedagogickej praxe sa v 90 . rokoch stali inovácie vyučovacích metód a vyučovacích stratégií (Kosová \& Porubský, 2011b). Tieto inovácie následne ovplyvňovali kurikulum škôl a mali tendenciu viest' k podstatným systémovým zmenám v cieloch vzdelávania, obsahovej zložke predmetov, vyučovacích stratégiách, ale aj v hodnotení výsledkov.

$\checkmark$ tomto období, ktoré možno nazvat' aj ako obdobie reforiem zdola (top-down reformy), vznikli aj prvé koncepcie výchovy a vzdelávania (predstavovali bottom-up reformy) - Duch školy (Turek, 1993), neskôr Konštantín (MŠVVaŠ SR, 1994). Ani jeden z programov však nebol schválený a realizovaný. Až po takmer desiatich rokoch čakania, bol v roku 2002 však vládou schválený dokument Milénium ako Koncepcia rozvoja výchovy a vzdelávania na najbližších 10-15 rokov (Rosa, Turek \& Zelina, 2001). Ani tento dokument však nepriniesol reálnu zmenu v edukačnej praxi, pretože išlo o ideový dokument. V máji roku 2008 bol prijatý nový školský zákon (Zákon č. 245/2008 Z. z. o výchove a vzdelávaní), ktorý do istej miery preberá ideový základ Milénia (Zelina, Rosa, \& Turek, 2001). Základnou a zásadnou zmenou, ktorú tento zákon priniesol, bola deklarácia väčšej slobody prejavená povinnost’ou vytvárat' si školské vzdelávacie programy vychádzajúce zo štátnych vzdelávacích programov. Problémom však bolo, že kým v 90 . rokoch bola požiadavka na zmenu (aj obsahovú, cielovú, evalvačnú) organizovaná zdola od samotných učitel'ov, v roku 2008 sa požiadavka na zmenu stala politickou témou a išlo o zmenu „zhora“ (bottom-up reforma) (viac Kosová \& Porubský, 2011b).

Nové štátne kurikulum pre gymnáziá vystavané na kompetenčnom modeli vznikalo, na rozdiel od štátneho vzdelávacieho programu pre základné školy, už pred rokom 2008. Východiskom pre jeho tvorbu bol projekt ESF Kurikulárna transformácia všeobecno-vzdelávacej zložky stredoškolského vzdelávania $v$ procese prípravy mládeže na trh práce (2004-2006) zastrešený P. Černekom (Kríž, 2008). Projekt realizoval Štátny pedagogický ústav a ako prvý na Slovensku do tvorby obsahu vzdelávania vniesol prvky dvojúrovňovej tvorby vzdelávacích programov a orientáciu na rozvoj kompetencií žiaka. Najdôležitejším výstupom projektu bolo vytvorenie Rámcového vzdelávacieho programu ako základného pedagogického dokumentu vytvoreného na úrovni štátu. Rámcový vzdelávací program (ŠPú, 2006) bol na webovom sídle Štátneho pedagogického ústavu predložený na diskusiu. Mal nahradit' $v$ tom čase platné učebné plány, učebné osnovy a vzdelávacie štandardy pre stredné školy a stat' sa záväzným pedagogickým dokumentom. Obsah vzdelávania bol rozdelený do siedmich vzdelávacích oblastí a jeho základná štruktúra vychádza z klúčových kompetencií definovaných v rámci projektu OECD DeSeCo (Rychen \& Salganik, 2003) - 1. Jazyk a komunikácia, 2. Matematické myslenie a práca s informáciami, 3. Zdravie a pohyb, 4. Človek a príroda, 5. Jedinec, 6. Spoločnost', 7. Kultúra. Obsah vzdelávania v oblasti cudzie jazyky nebol súčast’ou RVP vzhladom na to, že vzdelávacie štandardy jazykov obsahuje Európsky referenčný rámec a návrh štátneho kurikula ho v plnej 
116 miere akceptoval. Nové kurikulum sa nezavádzalo plošne, ale bolo ponúknuté školám ako alternatíva doterajšieho vzdelávania, $v$ procese experimentálneho overovania. 0 výsledkoch experimentálneho overovania však nie sú dostupné relevantné informácie. V praxi to teda znamenalo, že aj pred školskou reformou v roku 2008 mohli byt' na Slovensku gymnáziá, ktoré si vytvárali svoje školské vzdelávacie programy. O ich počte, resp. o tom, ktoré gymnáziá to boli, však neexistujú záznamy, realizátor projektu ich nesledoval, sledované boli len tri gymnáziá v štádiu prípravy učebných osnov predmetov podla rámcových vzdelávacích programov (ŠPú, 2007).

Proces kurikulárnych zmien $v$ oblasti všeobecného vzdelávania pokračoval aj po roku 2008. Vzhladom na požiadavky na zmenu a opravu štátnych vzdelávacích programov, ale aj v súvislosti s vypracovanou Správou o stave školstva (MŠVVaŠ SR, 2013) (ktorá však nebola oficiálne zverejnená), boli v roku 2015 realizované inovácie štátnych vzdelávacích programov. Opätovne sa však zopakoval proces z roku 2008: učitelia neboli prítomní pri dizajnovaní kurikula, inovácii vzdelávacích cielov a obsahu nepredchádzal výskum a učitelia neboli vopred informovaní o zmene. Inovácia štátneho kurikula v roku 2015 priniesla gymnáziám ešte väčšiu vol'nost' $v$ tvorbe obsahu v rámci školských vzdelávacích programov, rámcový učebný plán vymedzuje počty hodín pre jednotlivé predmety za stupeň vzdelania a obsah má charakter výstupových štandardov. Pozitívnou úpravou v štátnych vzdelávacích programoch pre gymnáziá je posilnenie praktického vyučovania formou povinných laboratórnych cvičení, ktoré sú povinné pre každý predmet, ktorý si to vyžaduje (fyzika, chémia, biológia). Významnou mierou sa tak posilnila výučba prírodovedných predmetov. Negatívnym javom inovácie štátneho kurikula je, že tak ako v roku 2008, ani v roku 2015 nedošlo k inovácii dôležitého dokumentu, a to Ciel'ových požiadaviek na maturitné skúšky (MŠVVaŠ SR, 2013). Kým vzdelávacie štandardy štátneho vzdelávacieho programu vychádzajú z kompetenčného modelu kurikula (aj napriek formálnym chybám ide o významný kvalitatívny posun), cielové požiadavky akcentujú encyklopedické vedomosti. Pre tzv. „maturitné predmety“ sa tak klúčovým dokumentom stávajú cielové požiadavky na maturitné skúšky a výučba (aj napriek posilneniu laboratórnych cvičení - vid' Rámcové učebné plány inovovaného štátneho vzdelávacieho programu, MŠVVaŠ SR, 2015), ostáva na úrovni osvojovania vedomostí.

Rok 2018 sa po desiatich rokoch od prvej vel'kej školskej reformy bude pravdepodobne spájat's d'alšou reformou vzdelávania. Jej východiskom je dokument Učiace sa Slovensko (MŠVVaŠ SR, 2017), ktorý bol vypracovaný externými expertmi na žiadost' vtedajšieho ministra školstva. Na základe spomínaného dokumentu nie je zrejmé, aké by mali byt' d'alšie kroky skvalitňovania všeobecného vzdelávania. Väčší dôraz sa kladie na odborné školstvo a z dokumentu vyplýva snaha o zvýšenie kvality výučby na gymnáziách formou limitovania počtu prijímaných žiakov. Do akej miery budú tieto zámery naplnené však nie je $v$ tejto chvíli známe, pretože nastupujúca ministerka po nástupe do funkcie $v$ roku 2017 dokument prijala len ako ideový základ konkrétnych zmien v školstve. Aj napriek existencii čiastkových výsledkov výskumu o prijatí a vnímaní školskej reformy z roku 2008, dôkazom o dopadoch tejto reformy na kvalitu vzdelávania na Slovensku (napr. vd’aka celonárodným externým testo- 
vaniam piatakov a deviatakov, alebo výsledkom PISA), sa však aj následná reforma realizuje len formou zhora (z ministerstva školstva) nariadených zmien (bottom-up reforma) a neexistujú zatial' dôkazy o hl'adaní ciest, ako podporovat' zmenu $v$ školstve od samotných učitel'ov.

\subsection{Názory a postoje učitel’ov ku kurikulárnej reforme}

Otázky reformy školstva patria medzi témy, ktorým sa venujú výskumníci v rozličných kontextoch. B. Kosová \& Š. Porubský (2011a) uvažujú o systéme synergických reforiem, ktoré sa viac približujú chápaniu pojmu transformácia edukačného systému, tzn. viacúrovňový sociálny proces permanentných zmien edukačnej reality a konštruovania nového vzdelávacieho systému (Walterová, 2004). Procesy, ktoré prebiehali v slovenskom školskom systéme v rokoch 2008-2009 istým spôsobom vytvárali predpoklady na transformáciu edukačného systému, avšak v konečnom dôsledku (aj na základe vymedzenia pojmu reforma) je možné hovorit’ o čiastkových reformách (teda úpravách) niektorých elementov zložitého komplexu.

Pre slovenskú kurikulárnu reformu platí, že bola unikátnou skúsenost’ou (Kosová \& Porubský, 2011a), najmä kvôli (ne)pripravenosti učitel'ov v praxi (Pavlov, 2013). Viacerí autori (Brundrett, Duncan, \& Rhodes, 2010; Connelly \& Clandinin, 1988; Hargreaves, 2005; Porubský et al., 2016; Terhart, 2013; Valica et al. 2011 a i.) pritom uvádzajú, že učitel' a jeho profesionalita je ústredným činitel'om kurikulárnej reformy. Fullan (2007) konštatuje, že úspešná reforma potrebuje systém krokov, ktoré sa nedajú preskočit'; uvádza tri procesy: inicializácie, implementácie a inštitucionalizácie. McKenney a Reeves (2012) popisujú všeobecný model riadenia kurikulárnej zmeny, ktorú vníma v dvoch rovinách: 1. výskum - dizajn - hodnotenie; výsledkom je vystavaná a premyslená intervencia; 2. prieskum - modelovanie - reflexia, výsledkom je teoretické pochopenie zmien. Tento model poukazuje na dôležitost' výskumne podloženej a overenej zmeny, ktorej výsledkom je nielen vytvorený model kurikula, ale aj jeho teoretické pochopenie u všetkých aktérov. Na Slovensku sa komplexne o reformnom procese nedá uvažovat' vo vyššie pomenovaných dimenziách. Chýbajúci výskum, teoretické štúdium, dizajnovanie kurikula, jeho overenie v praxi a následná intervencia spôsobili, že učitelia základných škôl (viac vid' Porubský et al., 2016) sa nestotožnili s realizovanou zmenou. V prípade gymnázií síce absentoval vstupný výskum, avšak dizajnovanie a overenie kurikula prebiehalo vd’aka národnému projektu Štátneho pedagogického ústavu. To, čo je pre reformu v základných a gymnáziách spoločné, je absencia prípravy učitelov na zmenu, ktorá by podnietila teoretické uchopenie realizovaných zmien.

Podporu myšlienke pripravenej a premyslenej zmeny v školstve podporuje aj d'alší autor, E. Terhart (2013), ktorý upozorňuje na rezistenciu učitel'ov voči školským reformám a dôvody klasifikuje do štyroch perspektív - sociopolitickej (neexistuje konsenzus o tom, čo sú vlastne edukačné problémy a ktoré témy či vedomosti sú považované za klúčové; to vyvoláva u učitel'ov únavu až znechutenie $z$ toho, že preberajú iniciatívu $v$ rozvoji alebo adaptovaní vedomostí pre školské prostredie), 
118 psychodynamickej (existuje konsenzus o edukačných problémoch, avšak nereálne očakávania na školy vytvárajú politické prekážky pre uplatnenie použitelných vedomostí), pragmatickej (školský systém a školy sú komplexným systémom s rôznymi ciel'mi, čím sa vytvárajú prekážky a formovanie obsahu je len t’ažko plánovatel'né) a kontemplatívnej (školský systém nie je riadený presnými ciel'mi alebo očakávaniami; ide o multisystém ovplyvňovaný vlastnou vnútornou dynamikou). V prípade slovenskej školskej reformy na gymnáziách došlo k väčšiemu či menšiemu prepojeniu väčšiny perspektív, predovšetkým sociopolitickej a psychodynamickej. Tento jav súvisí s absenciou relevantného pedagogického výskumu, dlhodobejšieho dizajnovania a overovania dopadov navrhovaných zmien. $V$ prípade kurikulárnej reformy $\mathrm{v}$ gymnáziách síce $\mathrm{k}$ akémusi overeniu došlo, avšak tento proces nebol nijako monitorovaný ani evaluovaný. Ak vychádzame z teórie McKenney \& Reeves (2012), v podstate $\checkmark$ realizovanej školskej reforme na gymnáziách, okrem premysleného spoločného dizajnovania kurikula štátnej inštitúcie a škôl, nedošlo $k$ žiadnej z predchádzajúcich ani nasledujúcich fáz, a teda je málo pravdepodobné, že učitelia teoreticky pochopili očakávané zmeny a mohla prebehnút' premyslená intervencia.

\subsection{Výskumný problém a ciele}

Stále nemáme dostatok empirických zistení o tom, nakol'ko sú učitelia slovenských gymnázií spokojní s vývojom školstva, nakol'ko cítili potrebu reformovat' ho a v ktorých oblastiach považovali doterajšie etapy reformy za prínosné. $V$ snahe prispiet' $\mathrm{k}$ riešeniu tohoto problému sme stanovili nasledujúce výskumné ciele:

1. Ciel' 1. Postihnút' úroveň a valenciu spokojnosti učitel'ov gymnázií s vývojovými trendmi $v$ slovenskom školstve $v$ relatívne nedávnej minulosti. Pri jeho formulácii sme mali na mysli najmä hodnotovú dimenziu kurikulárnej reformy ako sociálneho javu, tvoriacu dôležitý kontext ostatných hodnotiacich aktivít.

2. Ciel' 2. Zistit', nakol'ko bolo uskutočnenie reforiem na slovenských gymnáziách podla učitelov potrebné a do akej miery sa na tom podielali špecifické oblasti kurikula. Opät' ide hlavne o hodnotový a motivačný aspekt reformy, ktorý súvisí s pripravenost'ou učitelov prijat' prípadné zmeny (nepotrebné reformy sú obvykle neúspešné).

3. Ciel' 3. Zmapovat', $v$ ktorých oblastiach učitelia gymnázií pocítili reformu ako prínosnú a $v$ ktorých nie.

\section{Metóda}

\subsection{Výskumný dizajn a premenné}

V tomto článku analyzujeme vybrané aspekty rozsiahlejšieho exploračného ex post facto výskumu. Ten vychádzal z ratingov, prostredníctvom ktorých sa učitelia vyjadrovali k rôznym aspektom kurikulárnej reformy, zavádzanej na Slovensku od roku 
2008. Výskum paralelne mapoval tri úrovne slovenských škôl: materské, základné a gymnáziá.

Naše výsledky vypovedajú o názoroch podsúboru gymnaziálnych učitel'ov v troch tematických celkoch $v$ súlade s vyššie formulovanými ciel'mi. K dosiahnutiu ciela 1 (zistenie spokojnosti s vývojom školstva) prispievajú ratingy šiestich položiek dotazníka a jedna z nich vychádzajúca, „Index spokojnosti“, ako ich aritmetický priemer. K naplneniu ciel'a 2 (retrospektívnej reflexie potreby reformy), slúži d'alších šest' položiek a opät' ich priemer, všeobecnejší „Index naliehavosti“. Dosiahnut' ciel' 3 (zameraný na oblasti prínosov reformy), umožňuje 21 položiek a ich priemer - „Index prínosu“. Názory gymnaziálnych učitel’ov hlbšie skúmame z pohl'adu podskupín (rod, dĺžka odbornej praxe, pracovná pozícia) a tiež v komparácii s „najpríbuznejším“ podsúborom vzorky - učitel'mi 2. stupňa základných škôl.

Položkové premenné chápeme dvojako: (1) ako nominálne, kde vychádzame z relatívnych početností vol'by bodov stupnice, (2) ako ordinálne, kde sa opierame najmä o kvartilové charakteristiky. Parametrické štatistiky používame hlavne ako doplnkový údaj. Toto kombinované chápanie má svoje opodstatnenie, lebo prispieva k lepšiemu spoznaniu dát. Všeobecnejšie indexy považujeme za intervalové likertovské škály, ktoré zase umožňujú dáta analyzovat' na vyššej úrovni, než v prípade čiastkových položiek.

\subsection{Použitá metodika a jej vlastnosti}

Nástroj, ktorý sme použili, je mierne modifikovanou variantou survey dotazníka IKR-2014, vytvoreného a použitého v rámci projektu výskumu kurikulárnej reformy v roku 2014. Vzhl'adom na to, že zber dát sa uskutočňoval v roku 2015 v novembri, učitelia gymnázií v tomto čase inovovali školské vzdelávacie programy, a preto boli do dotazníka doplnené otázky zist'ujúce názory učitelov na inováciu štátnych vzdelávacích programov a na hodnotenie procesu zavádzania inovácie. Originálna metodika, ktorá bola v modifikovanej verzii neznemená, je založená na explorácii jednotlivých „tém“ (celkovo 18), kde každá téma má spoločný všeobecný „uvádzací“ výrok, konkretizovaný jednotlivými ratingovými položkami. Napr. uvádzací výrok k téme č. 1 , „Uved’te, ako ste spokojný/á s celkovým vývojom školstva za posledných 6 rokov“, je konkretizovaný položkami ako: „kvalita školstva sa stala prioritou“, „došlo k výraznej pozitívnej zmene“, „s reformami by sa nemalo skončit““. Ku každej položke sa respondent vyjadruje nezávisle na iných (nejde o ipsatívne meranie), vol'bou jednej z možností „vôbec nesúhlasím“, „skôr nesúhlasím“, „skôr súhlasím“, „určite súhlasím“, t.j. v podstate na 4-bodovej ordinálnej hodnotiacej stupnici bez neutrálnej pozície.

Tematické zoskupovanie položiek IKR-2014 vychádza z publikovaného pôvodného konceptuálneho modelu (Porubský et al., 2014) a má umožnit' sumarizáciu pedagogicky podobných významov do všeobecnejších skóre - indexov. Nástroj sme za účelom validizácie najprv podrobili obsahovej analýze z hladiska obsahového pokrytia konštruktu (Poliach, 2015). Ex post facto sme vykonali aj jeho položkovú analýzu, 
so zámerom overit' vnútro-tematickú konzistenciu a faktorovú štruktúru. Na tieto účely sme využili iný súbor dát $(n=954)$ než tie, ktoré interpretujeme v tomto výskume. Opierali sme sa jednak o ordinálnu variantu Cronbachovho koeficientu alfa (počítanú z polychorických korelácií), ako aj o perspektívnejší koeficient McDonald omega $(\omega h)$. Latentné faktory v pozadí tematických okruhov sme identifikovali prostredníctvom faktorovej analýzy vychádzajúcej z polychorických korelácií (Revelle \& Zinbarg, 2009). Vnútorná konzistencia tematických skupín položiek, na ktorých sú v tomto výskume založené výpočty indexov „spokojnosti“, „naliehavosti“ a „prínosu“ $k$ cielom 1 až 3 , mala koeficienty: $1 . \alpha=0,76, \omega h=0,73,2 . a=0,87, \omega h=$ $0,69,3 . a=0,97, \omega h=0,85$. Zatial' čo prvé dva okruhy vykazujú dobrú tematickú konzistenciu, $v$ tret'om alfa signalizuje, že pravdepodobne obsahuje niekol'ko nadbytočných položiek. Ďalšie informácie o nástroji (napr. polychorické korelácie skupín položiek a modely alternatív faktorových riešení) sme publikovali na inom mieste (Poliach, 2016) a presahujú záber tejto štúdie.

\subsection{Administrácia, výskumná vzorka a spracovanie údajov}

Cielovú populáciu predstavujú všetci učitelia gymnázií v SR - v čase výskumu približne 5500). Administráciu sme uskutočnili na jeseň 2015. Respondenti boli k účasti vyzvaní prostredníctvom emailu adresovanom vedeniu všetkých gymnázií SR. Účast' respondentov bola dobrovol'ná, príležitost' zapojit' sa trvala niekol'ko týždňov. Vol'ba dostupného výberu respondentov bola riešením problému, ktorý vznikol počas oslovovania riaditel'ov gymnázií vybraných náhodným výberom - odmietli spoluprácu pri realizácii výskumu z dôvodu ochrany učitelov pred pret’ažovaním zo strany výskumníkov.

Pri administrácii bol použitý on-line systém snímania dotazníka IKR-2014, v ktorom boli niektoré aspekty zadávania ošetrené už na vstupe (ako prevencia nekorektných odpovedí), čo zjednodušilo následnú prípravu dát na analytickú fázu spracovania. On-line snímanie dát je v súčasnosti skúmané z hladiska validity, reliability a d’alších psychometrických údajov. Okrem uvádzaných výhod (pokrytie, nízke náklady) sa ako najzretel'nejší vynára problém neodpovedania, ktoré spôsobuje často „návratnost““ nižšiu ako 1 \% (Vehovar \& Manfreda, 2008). Z hladiska chýb merania však viaceré novšie štúdie na vel'kých súboroch dospeli k záveru, že medzi výsledkami tradičných a on-line foriem administrácie survey nie sú rozdiely (Dodou \& de Winter, 2014; Wladis \& Samuels, 2016). Za problematické sa nad'alej považujú snahy korigovat' nedostatok reprezentatívnosti on-line samovýberu v stratifikovaných vzorkách vážením (Blasius \& Brandt, 2010; Callegaro \& Baker, 2014). Výskumná vzorka, ktorá ju reprezentuje pre účely tejto analýzy, má rozsah 313 respondentov (5,69 \% z populácie). Hlavné aspekty diverzity vzorky z pohladu rodu, pracovnej pozície a dížky odbornej praxe spresňujú kontingenčné tabul'ky 1 a 2 . 
Tabul'ka 1 Zloženie výskumnej vzorky - premenné Rod a DÍžka odbornej praxe

\begin{tabular}{|c|c|c|c|c|c|c|c|c|c|c|}
\hline \multirow{2}{*}{$n=313$} & \multicolumn{9}{|c|}{ Dížka odbornej praxe } & \multirow{2}{*}{ Spolu } \\
\hline & & & 5 & 10 & 15 & 20 & 25 & 30 & 35 & \\
\hline \multirow{4}{*}{ Rod } & \multirow{2}{*}{$f$} & počet & 26 & 25 & 49 & 34 & 36 & 34 & 31 & 235 \\
\hline & & $\% \mathrm{z} \mathrm{n}$ & $8,3 \%$ & $8,0 \%$ & $15,7 \%$ & $10,9 \%$ & $11,5 \%$ & $10,9 \%$ & $9,9 \%$ & $75,1 \%$ \\
\hline & \multirow{2}{*}{$\mathrm{m}$} & počet & 8 & 11 & 16 & 18 & 8 & 6 & 11 & 78 \\
\hline & & $\% \mathrm{z} \mathrm{n}$ & $2,6 \%$ & $3,5 \%$ & $5,1 \%$ & $5,8 \%$ & $2,6 \%$ & $1,9 \%$ & $3,5 \%$ & $24,9 \%$ \\
\hline \multirow[t]{2}{*}{ Spolu } & & počet & 34 & 36 & 65 & 52 & 44 & 40 & 42 & 313 \\
\hline & & $\% \mathrm{z} \mathrm{n}$ & $10,9 \%$ & $11,5 \%$ & $20,8 \%$ & $16,6 \%$ & $14,1 \%$ & $12,8 \%$ & $13,4 \%$ & $100,0 \%$ \\
\hline
\end{tabular}

Vysvetlivky: Rod - pohlavie respondentov, dlžka odbornej praxe (šírka pásiem je 5 rokov).

Relatívne početnosti sú počítané z celkového rozsahu vzorky $(n=313)$.

Tabul'ka 2 Zloženie výskumnej vzorky - premenné Pracovná pozícia a DÍžka praxe

\begin{tabular}{|c|c|c|c|c|c|c|c|c|c|c|}
\hline \multirow{2}{*}{$n=313$} & \multicolumn{9}{|c|}{ Dížka odbornej praxe } & \multirow{2}{*}{ Spolu } \\
\hline & & & 5 & 10 & 15 & 20 & 25 & 30 & 35 & \\
\hline \multirow[t]{4}{*}{$\begin{array}{l}\text { Pracovná } \\
\text { pozícia }\end{array}$} & \multirow[t]{2}{*}{ uč } & počet & 34 & 33 & 57 & 35 & 30 & 29 & 25 & 243 \\
\hline & & $\%$ z $n$ & $10,9 \%$ & $10,5 \%$ & $18,2 \%$ & $11,2 \%$ & $9,6 \%$ & $9,3 \%$ & $8,0 \%$ & $77,6 \%$ \\
\hline & \multirow{2}{*}{ ved } & počet & 0 & 3 & 8 & 17 & 14 & 11 & 17 & 70 \\
\hline & & $\% \mathrm{z} n$ & $0,0 \%$ & $1,0 \%$ & $2,6 \%$ & $5,4 \%$ & $4,5 \%$ & $3,5 \%$ & $5,4 \%$ & $22,4 \%$ \\
\hline \multirow[t]{2}{*}{ Spolu } & & počet & 34 & 36 & 65 & 52 & 44 & 40 & 42 & 313 \\
\hline & & $\% \mathrm{z} n$ & $10,9 \%$ & $11,5 \%$ & $20,8 \%$ & $16,6 \%$ & $14,1 \%$ & $12,8 \%$ & $13,4 \%$ & $100,0 \%$ \\
\hline
\end{tabular}

Vysvetlivky: PPOZ - pracovná pozícia (uč = učitel', ved = vedúci pracovník). Dlžka odbornej praxe: šírka pásiem je 5 rokov. Relatívne početnosti sú počítané z celkového rozsahu vzorky $(n=313)$.

\section{Výsledky}

Výsledky prezentujeme podla výskumných cielov v tejto štruktúre: 1 . Zostupne zoradené tabelované výsledné ratingy položiek vo formáte parametrickom i neparametrickom. 2. Ked’že do článku by nevošli vizualizácie distribúcií položkových ratingov, upozorňujeme v komentároch aspoň u vybraných na \% dominanty a testujeme podobnost' rozdelení ratingov vnútri tematického okruhu. 3. Porovnávame indexy podskupín podla rodu, dížky praxe, pracovnej pozície a podsúborov gymnaziálnych učitel'ov a učitel'ov 2 . stupňa ZŠ. 


\subsection{Výsledky analýz k tematickému okruhu 1}

Uvádzací výrok tematického okruhu 1 znie: „Uved'te, ako ste spokojný/á s celkovým vývojom a stavom školstva na Slovensku za posledných 6 rokov“. Ratingová stupnica je zostavená takto: „určite nesúhlasím“ = 1 , „skôr nesúhlasím“ = 2, „skôr súhlasím“ $=3$, „určite nesúhlasím“ $=4$. Z týchto čísiel boli vypočítané príslušné parametrické i neparametrické deskriptívne charakteristiky. Poradie položiek zoradených zostupne (t.j. od najpozitívnejšie hodnotených) podla mediánu ako primárneho a priemeru ako sekundárneho klúča je v tabul'ke 3.

Tabul'ka 3 Deskriptívne štatistiky premenných okruhu 1 ( $\mathrm{n}=313$, zostupne)

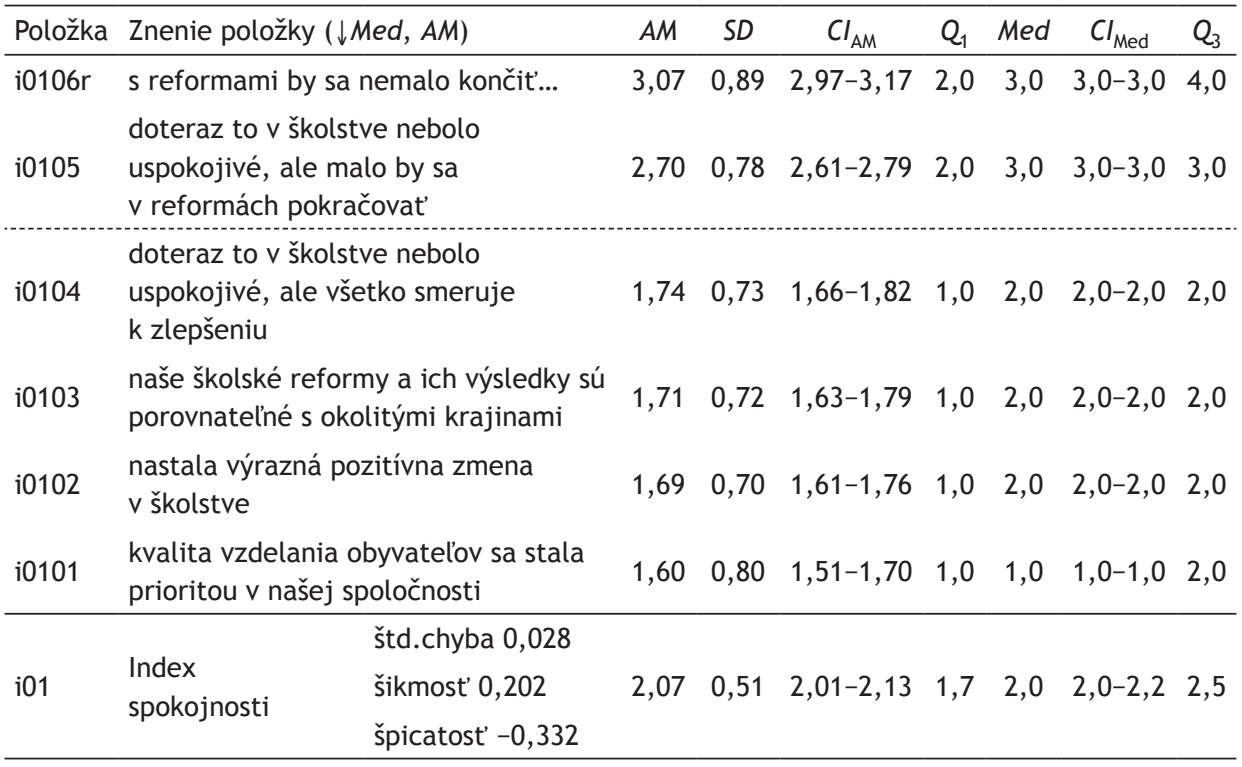

Vysvetlivky: * pôvodná položka i0106 je reprezentovaná otočenou variantou i0106r. AM - aritmetický priemer, $S D$ - smerodajná odchýlka výberová, $C_{A M}$ - interval spol'ahlivosti priemeru, $Q_{1}-1$. kvartil, Med - medián (2. kvartil), $C_{\text {Med }}$ - interval spol’ahlivosti mediánu, $Q_{3}-3$. kvartil. Čiarkovaná čiara oddeluje položky hodnotené prevažne súhlasne (hore) od položiek hodnotených prevažne nesúhlasne (dole).

Analýza na úrovni jednotlivých položiek. Tabul'ku 3 možno chápat' ako rozdelenú na dve pásma (s hranicou naznačenou čiarkovanou čiarou). $V$ hornom pásme sú dve položky podobného obsahu, ktorých medián má hodnotu 3. S výrokom i0106r „s reformami by sa nemalo končit“" vyjadruje silný súhlas $36 \%$ a mierny súhlas $34 \%$ gymnaziálnych učitelov. S i0105 silne súhlasí $10 \%$ a mierne 53 \% učitelov. Ostatné položky majú medián 2 , t.j. viac ako polovica respondentov s nimi skôr nesúhlasí. Jednotlivo to vyzerá nasledovne (kód položky, \% silného nesúhlasu, \% mierneho nesúhlasu): i0104 (41\%, $42 \%$ ), i0103 (38 \%, $40 \%$ ), i0102 (44\%, $45 \%$ ), i0102 (44\%, 45 \%), i0101 (57 \%, 28 \%). Najvyššie \% volby „neviem“ sa objavilo u položky i0103 
„naše školské reformy sú porovnatel'né...“. Pomerne vysoká neistota (6-7 \%) sa však prejavuje aj u dvoch najpozitívnejšie hodnotených položiek.

Testovanie podobnosti hodnotení série položiek. Už intervaly spolahlivosti naznačujú výraznú odlišnost' distribúcií položiek i0106r a i0105 od všetkých ostatných. Výsledok testovania podobnosti rozdelení série položiek Friedmanovým testom $(p<0,001)$ vedie $\mathrm{k}$ záveru, že respondenti tieto dve položky skutočne hodnotia významne pozitívnejšie. Kendallovo $W=0,449$ možno považovat' za stredne silný efekt.

Analýza na úrovni sumárneho „Indexu spokojnosti“. Index má mediánovú hodnotu 2, t.j. u učitelov gymnázií v skúmanom období celkovo prevažovala mierna nespokojnost' s vývojom školstva. Medzi podskupinami učitelov a vedúcich sa neobjavil významný rozdiel v distribúcii indexu. Podobne ani medzi podskupinami učitelov z hl'adiska dížky praxe. V porovnaní so súbežne monitorovanou skupinou učitel'ov 2. stupňa ZŠ sa index prejavuje o niečo vyšším zastúpením pozitívnejších hodnotení. Pri rovnakom mediáne 2 dosiahli gymnaziálni učitelia $A M=2,07$, zatial' čo učitelia 2. stupňa ZŠ $A M=1,98$. Rozdiel je síce významný $(p=0,016)$, ale jeho vecná signifikancia je nízka (Cohenovo $d=0,173$ ).

\subsection{Výsledky analýz k tematickému okruhu 2}

Uvádzací výrok tematického okruhu 2 znie: „Potrebu zmenit’ učebné osnovy platné pred rokom 2008 som pocit’oval/a ako naliehavú v týchto oblastiach“. Ordinálna hodnotiaca stupnica aj postup zoradenia položiek boli rovnaké, ako v prípade okruhu 1.

Tabul'ka 4 Deskriptívne štatistiky premenných okruhu 2 ( $\mathrm{n}=313$, zostupne)

\begin{tabular}{|c|c|c|c|c|c|c|c|c|}
\hline Položka & Znenie položky $(\downarrow$ Med,$A M)$ & $A M$ & $S D$ & $C I_{A M}$ & $Q_{1}$ & Med & $\mathrm{Cl}_{\text {Med }}$ & $Q_{3}$ \\
\hline i0204 & $\begin{array}{l}\text { modernizácia učebných metód, } \\
\text { stratégií a foriem }\end{array}$ & 3,35 & 0,69 & $3,27-3,42$ & 3,0 & 3,0 & $3,0-4,0$ & 4,0 \\
\hline i0206 & podpora pozitívnej klímy $v$ triede & 3,34 & 0,74 & $3,25-3,43$ & 3,0 & 3,0 & $3,0-4,0$ & 4,0 \\
\hline i0205 & $\begin{array}{l}\text { vyššia akceptácia špecifík } \\
\text { a osobitostí žiaka }\end{array}$ & 3,10 & 0,76 & $3,02-3,19$ & 3,0 & 3,0 & $3,0-3,0$ & 4,0 \\
\hline i0203 & $\begin{array}{l}\text { decentral. moci a potreba tvorby } \\
\text { školského vzdeláv. programu }\end{array}$ & 2,86 & 0,89 & $2,75-2,96$ & 2,0 & 3,0 & $3,0-3,0$ & 3,0 \\
\hline i0202 & ciele a vzdelávacie výstupy & 2,84 & 0,84 & $2,74-2,93$ & 2,0 & 3,0 & $3,0-3,0$ & 3,0 \\
\hline i0201 & učivo a učebné obsahy & 2,70 & 0,94 & $2,60-2,81$ & 2,0 & 3,0 & $3,0-3,0$ & 3,0 \\
\hline \multirow{3}{*}{ i02 } & štd. chyba 0,034 & \multirow{3}{*}{3,03} & \multirow{3}{*}{0,59} & \multirow{3}{*}{$2,96-3,10$} & \multirow{3}{*}{2,7} & \multirow{3}{*}{3,0} & \multirow{3}{*}{$3,0-3,0$} & \multirow{3}{*}{3,5} \\
\hline & Index & & & & & & & \\
\hline & špicatost' 0,583 & & & & & & & \\
\hline
\end{tabular}

Vysvetlivky: $A M$ - aritmetický priemer, $S D$ - smerodajná odchýlka výberová, $C_{A M}$ - interval spolahlivosti priemeru, $Q_{1}-1$. kvartil, Med - medián (2. kvartil), $C I_{\text {Med }}$ - interval spolahlivosti mediánu, $Q_{3}-3$. kvartil. 
Analýza na úrovni jednotlivých položiek. Všetky položky dosiahli ratingy zodpovedajúce pozícii 3 na ordinálnej stupnici, t.j. táto tabul'ka (4) nemá „zónu negatívnych hodnoteni". Vyjadrené formou relatívnych početností, je nasledovné (kód položky, \% silného súhlasu, \% mierneho súhlasu): i0204 (43\%, $45 \%$ ), i0206 (44\%, $42 \%$ ), i0205 (28\%, $50 \%$ ), i0203 (22\%, $42 \%$ ), i0202 (20\%, $44 \%)$, i0201 (19\%, $41 \%$ ). Najčastejšie reakcie „neviem“ sa objavili v položke i0203 (10\%). Z pohladu učitelov asi nebola jednoznačne formulovaná, nie každý tvorbu školského vzdelávacieho programu chápe ako formu decentralizácie moci.

Testovanie podobnosti hodnotení série položiek. Intervaly spolahlivosti pre mediány prvých dvoch položiek tabul'ky i0204 a i0206 naznačujú vyššie ratingy, než u nasledujúcich. $V$ testovaní distribúcií Friedmanovym testom sa tieto skutočne signifikantne líšia $(p<0,001)$, hoci z hladiska vecnej signifikancie ide iba o malý efekt (Kendall $W=0,18$ ).

Analýza na úrovni sumárneho „Indexu naliehavosti“. Index má medián 3 , t.j. prevažuje mierny súhlas $s$ tým, že potrebu reforiem cítili ako naliehavú. $\mathrm{V}$ tom sú podskupiny učitelov a vedúcich homogénne. Podobne sa neprejavili rozdiely z hl'adiska dížky odbornej praxe. Porovnanie „Indexu naliehavosti“ učitelov gymnázií a 2. stupňa ZŠ vedie k záveru, že učitelia gymnázií významne častejšie súhlasili $s$ výrokmi o potrebnosti reforiem (Mann-Whitney $p<0,001$, Cohenovo $d=0,287$ ). Zistený efekt je slabý, no nie zanedbatel'ný.

\subsection{Výsledky analýz $\mathrm{k}$ tematickému okruhu 3}

Uvádzací výrok tematického okruhu 3 znie: „Zavedenie štátneho vzdelávacieho programu a školského vzdelávacieho programu podla môjho názoru prinieslo“. Ordinálna hodnotiaca stupnica aj spôsob zoradenia položiek boli také isté, ako v prípade okruhov 1 a 2.

Tabul'ka 5 Deskriptívne štatistiky premenných okruhu 3 ( $\mathrm{n}$ = 313, zostupne)

\begin{tabular}{|c|c|c|c|c|c|c|c|c|}
\hline Položka & Znenie položky ( $\downarrow$ Med, AM) & $A M$ & $S D$ & $\mathrm{Cl}_{\mathrm{AM}}$ & $Q_{1}$ & Med & $C I_{\text {Med }}$ & $Q_{3}$ \\
\hline i0301 & väčšiu možnost' profilovat' školu & 2,95 & 0,82 & $2,85-3,04$ & 3,0 & 3,0 & $3,0-3,0$ & 3,0 \\
\hline i0303 & $\begin{array}{l}\text { možnosti zohl'adnit' regionálne } \\
\text { špecifiká školy }\end{array}$ & 2,78 & 0,78 & $2,68-2,87$ & 2,0 & 3,0 & $3,0-3,0$ & 3,0 \\
\hline i0313 & modernú koncepciu vzdelávania & 2,69 & 0,76 & $2,60-2,78$ & 2,0 & 3,0 & $3,0-3,0$ & 3,0 \\
\hline i0318 & $\begin{array}{l}\text { možnosti zohl'adnit' individuálne } \\
\text { potreby žiakov }\end{array}$ & 2,68 & 0,78 & $2,59-2,77$ & 2,0 & 3,0 & $3,0-3,0$ & 3,0 \\
\hline i0317 & zlepšenie metód a foriem výučby & 2,65 & 0,77 & $2,57-2,74$ & 2,0 & 3,0 & $3,0-3,0$ & 3,0 \\
\hline i0319 & väčšiu aktivitu a tvorivost' žiakov & 2,62 & 0,80 & $2,53-2,71$ & 2,0 & 3,0 & $3,0-3,0$ & 3,0 \\
\hline
\end{tabular}




\begin{tabular}{|c|c|c|c|c|c|c|c|c|}
\hline i0305 & väčšiu slobodu pre učitel'ov & 2,57 & 0,79 & $2,48-2,66$ & 2,0 & 3,0 & $3,0-3,0$ & 3,0 \\
\hline i0314 & $\begin{array}{l}\text { zlepšenie spôsobu vedenia } \\
\text { vyučovania v našej škole }\end{array}$ & 2,57 & 0,73 & $2,48-2,65$ & 2,0 & 3,0 & $3,0-3,0$ & 3,0 \\
\hline i0315 & zlepšenie vzdelávacích ciel’ov & 2,55 & 0,81 & $2,46-2,65$ & 2,0 & 3,0 & $3,0-3,0$ & 3,0 \\
\hline i0316 & $\begin{array}{l}\text { zlepšenie vzdelávacích obsahov } \\
\text { (učiva) }\end{array}$ & 2,45 & 0,82 & $2,36-2,54$ & 2,0 & 3,0 & $2,0-3,0$ & 3,0 \\
\hline i0302 & hlbšie prepojenie školy s praxou & 2,40 & 0,83 & $2,31-2,49$ & 2,0 & 2,0 & $2,0-3,0$ & 3,0 \\
\hline i0312 & zlepšenie kvality práce v škole & 2,40 & 0,78 & $2,30-2,49$ & 2,0 & 2,0 & $2,0-3,0$ & 3,0 \\
\hline i0307 & $\begin{array}{l}\text { zlepšenie manažovania práce } \\
\text { v našej škole }\end{array}$ & 2,35 & 0,81 & $2,25-2,44$ & 2,0 & 2,0 & $2,0-3,0$ & 3,0 \\
\hline i0311 & $\begin{array}{l}\text { zlepšenie pohl'adu verejnosti na } \\
\text { našu školu }\end{array}$ & 2,35 & 0,79 & $2,25-2,45$ & 2,0 & 2,0 & $2,0-3,0$ & 3,0 \\
\hline i0310 & $\begin{array}{l}\text { pozitívnejšie názory rodičov na } \\
\text { našu školu }\end{array}$ & 2,34 & 0,81 & $2,24-2,45$ & 2,0 & 2,0 & $2,0-3,0$ & 3,0 \\
\hline i0304 & $\begin{array}{l}\text { lepšiu komunikáciu školy } \\
\text { s rodinou žiakov }\end{array}$ & 2,31 & 0,76 & $2,22-2,41$ & 2,0 & 2,0 & $2,0-2,0$ & 3,0 \\
\hline i0308 & $\begin{array}{l}\text { zlepšenie klímy a atmosféry } \\
\text { v škole }\end{array}$ & 2,24 & 0,81 & $2,15-2,34$ & 2,0 & 2,0 & $2,0-2,0$ & 3,0 \\
\hline i0306 & $\begin{array}{l}\text { zlepšenie práce učitel'ského } \\
\text { zboru }\end{array}$ & 2,21 & 0,79 & $2,12-2,30$ & 2,0 & 2,0 & $2,0-2,0$ & 3,0 \\
\hline i0309 & $\begin{array}{l}\text { pozitívne pedagogické myslenie } \\
\text { učitel’ov našej školy }\end{array}$ & 2,20 & 0,79 & $2,11-2,29$ & 2,0 & 2,0 & $2,0-2,0$ & 3,0 \\
\hline i0321 & $\begin{array}{l}\text { zlepšenie vyučovacích výsledkov } \\
\text { našich žiakov }\end{array}$ & 2,11 & 0,77 & $2,02-2,20$ & 2,0 & 2,0 & $2,0-2,0$ & 3,0 \\
\hline i0320 & väčší záujem žiakov o učenie sa & 2,05 & 0,75 & $1,96-2,14$ & 2,0 & 2,0 & $2,0-2,0$ & 3,0 \\
\hline i03 & $\begin{array}{l}\text { Index } \\
\text { prínosu } \\
\text { reformy }\end{array}$ & 2,47 & 0,59 & $2,40-2,56$ & 2,0 & 2,6 & $2,5-2,7$ & 2,9 \\
\hline
\end{tabular}

Vysvetlivky: $A M$ - aritmetický priemer, $S D$ - smerodajná odchýlka výberová, $C l_{A M}$ - interval spolahlivosti priemeru, $Q_{1}$ - 1. kvartil, Med - medián (2. kvartil), $C I_{\text {Med }}$ - interval spolahlivosti mediánu, $Q_{3}-3$. kvartil. Čiarkovaná čiara oddel'uje zónu položiek hodnotených prevažne súhlasne (hore) od položiek hodnotených prevažne nesúhlasne (dole).

Analýza na úrovni jednotlivých položiek. V hornej časti tabul'ky 5 (nad čiarkovanou čiarou) sú položky s mediánom 3 , t.j. viac ako polovica respondentov ich hodnotila prevažne pozitívne. U najvyššie umiestneného výroku i0301 silný súhlas vyjadrilo až 23 \% a mierny 53 \% respondentov. Zostupne nasledujú (kód položky, \% silného súhlasu, \% mierneho súhlasu): i0303 (13\% a 55 \%), i0313 (10 \% a 54 \%), i0318 (10 \% a 54 \%), i0317 (8 \% a 57 \%), i0319 (10 \% a 50 \%), i0305 (7 \% a 50 \%), i03014 
126 (4 \% a 51 \%). Položky i0315 (8 \% a 48 \%) a i0316 (6 \% a $46 \%$ ) sa nachádzajú iba tesne nad hranicou medzi prevažne pozitívnymi a prevažne negatívnymi hodnoteniami. Žiadna položka nedosiahla medián 4 , čo by signalizovalo dominanciu silného súhlasu s touto oblast'ou prínosu.

V dolnej časti tabul'ky, t.j. v pásme skôr negatívnych hodnotení, sa objavujú položky s mediánom okolo 2, kde dominoval mierny nesúhlas prínosom reformy $v$ danej oblasti. V tomto prípade uvedieme údaje o nesúhlase (kód položky, \% mierneho nesúhlasu, \% silného nesúhlasu): i0302 (35\% a $14 \%$ ), i03012 (35\% a $12 \%$ ), i0307(31\% a $15 \%)$, i0311 (29 \% a $13 \%)$, i0310 (28 \% a $14 \%)$, i0304 (37\% a $13 \%)$, i0308 (36\% a $18 \%$ ), i0306 (41\% a $18 \%$ ), i0309 (37\% a $19 \%$ ), i0321 (43\% a $20 \%)$, i0320 (45\% a $22 \%$ ). Opät' žiadna položka nezískala medián 1 , ktorý by naznačoval prevahu silného nesúhlasu s oblast'ou prínosu. Vyššie \% odpovedí „neviem“ sa objavilo u i0310 (19\%), i0311 (19\%), i0304 (12\%), i0307 (11\%), i0308 (11\%), i0309 (10\%) a i0321 (10\%).

Testovanie podobnosti hodnotení série položiek. $\mathrm{Cl}_{\text {Med }}$ prvých 9 položiek sa neprekrývajú s $C I_{\text {Med }}$ posledných 6 položiek. Štatistickú rozdielnost' distribúcií indikujú aj výsledky Friedmanovho testu $(p<0,001)$, na čom sa zrejme podiel'a najmä negatívnejšie hodnotenie položiek i0320 a 3201 od väčšiny ostatných. Kendallovo $W=$ 0,145 indikuje iba slabý efekt, pravdepodobne súvisiaci s nadbytočnost’ou niektorých položiek $v$ rámci série.

Analýza na úrovni sumárneho „Indexu prínosu“. Hodnota mediánu tohoto indexu 2,6 (s intervalom spol'ahlivosti $C I_{\text {Med }}=2,5$ až 2,7) ukazuje iba vel'mi tesnú prevahu mierne pozitívneho uznania prínosov reformy nad mierne negatívnym hodnotením. Táto situácia sa nelíši ani u podskupín vedúcich a učitel'ov, ani u podskupín z hl'adiska dí̌ky praxe. $V$ porovnaní gymnázií a 2 . stupňa ZŠ dávajú učitelia základných škôl opät' nižšie ratingy, rozdiely sú však štatisticky významné $(p=0,001)$. Cohenovo $d=0,25$, teda ide opät' len o slabý, aj ked' nie celkom zanedbatel'ný efekt.

\section{Diskusia}

Slovenská kurikulárna reforma na gymnáziách (2008) mala podobný priebeh ako reforma kurikula pre základné školy. Jediným, a z pohl'adu prijatia zmien $v$ školstve aj podstatným, rozdielom bolo, že gymnaziálnej kurikulárnej reforme z roku 2008 predchádzal národný projekt Kurikulárna transformácia všeobecno-vzdelávacej zložky stredoškolského vzdelávania $v$ procese prípravy mládeže na trh práce realizovaný v rokoch 2004-2006 na Štátnom pedagogickom ústave. Vychádzajúc z Terhartovej štúdie (2013), ale aj nadväzujúc na McKenney \& Reeves model (2012) riadenia kurikulárnej zmeny, či Hargreavesovej (2005) teórie pripravenosti učitelov na kurikulárne zmeny by mal byt' zvolený model prípravy a realizácie kurikulárnej transformácie pre gymnáziá úspešnejší ako to bolo v prípade vôbec nepripravenej reformy základných škôl v roku 2008 (bližšie Kosová \& Porubský, 2011a,b; Porubský et al., 2014, 2016). Rozdiel bol predovšetkým v aktívnom zapojení zástupcov gym- 
názií do tvorby návrhu transformácie kurikula vznikajúcom ako súčast' národného projektu. Kurikulum vytvorené v roku 2008 sa líšilo od toho, ktoré bolo výstupom projektu v roku 2006. Odpovede respondentov gymnázií v oblasti spokojnosti s vývojom školstva na Slovensku, ako aj v oblasti naplnenia ich očakávaní majú prevažne negatívny charakter a potvrdzujú zistenia z dotazníkového šetrenia na základných školách z rokov 2015-2016. A aj takmer po desiatich rokoch od spustenia školskej reformy (2008 začiatok reformy, realizácia výskumu 2015-2016) učitelia hodnotia celý reformný proces viac negatívne ako pozitívne a nemyslia si, že priniesol pozitívnu zmenu v slovenskom školstve. Ich vlastné očakávania na zmenu neboli naplnené a reformu je možné charakterizovat' ako sklamanie a posilňuje sa rezistencia voči zmenám v školstve.

S ohl'adom na zistenia v oblasti očakávaných zmien priamo prepojených s kvalitou profesijných kompetencií učitelov gymnázií aj základných škôl (riadenie výučby, zvládanie disciplíny, zlepšovanie klímy triedy a pod.) sa domnievame, že je potrebné hlbšie skúmat' mikro úroveň kurikulárnych zmien. Mikroúroveň (priamy náhlad do triedy a do práce učitelov) by mohli odhalit', do akej miery a či vôbec došlo k zmenám v procese výučby $v$ kontexte reformy. Súčasne je otázkou aj to, či sú slovenskí učitelia dostatočne profesijne pripravení na realizáciu zmien, pretože ich odpovede na to, aké zmeny očakávajú od reformy naznačujú nedostatky $v$ oblasti profesijnej prípravy - čo vnímame ako d'alší impulz pre výskum.

$\checkmark$ rámci našej štúdie sme sa zamerali predovšetkým na to, ako sú učitelia gymnázií spokojní s reformnými snahami v oblasti školstva na Slovensku, a to najmä v kontexte s vel'kou reformou v roku 2008 (výskumný ciel' 1), hodnotenie súladu medzi očakávaniami učitel'ov od reformy a realizovanou zmenou (výskumný ciel' 2) a vnímanie prínosov reformy učitel'mi gymnázií (výskumný ciel' 3).

Zámerom výskumného ciela 1 bolo postihnút' úroveň a valenciu spokojnosti učitel'ov gymnázií $s$ vývojovými trendmi $v$ slovenskom školstve $v$ relatívne nedávnej minulosti. Medzi najzávažnejšie zistenia zarad'ujeme:

- Väčšina gymnaziálnych učitelov (takmer 9 z 10) sa domnieva, že kvalita vzdelania nepatrí medzi súčasnou spoločnost'ou uznávané hodnoty.

- Podobne 9 z 10 si nemyslí, že by v školstve v čase výskumu prebiehala výrazná pozitívna zmena.

- Paradoxne voči hore uvedenému sa však viac než dve tretiny učitelov gymnázií domnievajú, že v reformách treba pokračovat'.

Učitelia gymnázií sú v podstate proreformne orientovaní, t.j. väčšina je za ich pokračovanie. Sú však aj vel'mi nespokojní so stavom školstva v čase výskumu, pričom najmä v tom, že zo strany spoločnosti necítia, že by kvalitu vzdelávania považovala za hodnotu. Tento trend je zhruba rovnaký u podskupín vedúcich aj výkonných pracovníkov, tiež vo všetkých podskupinách z hl'adiska dížky praxe.

V porovnaní s učitel'mi základnej školy (Porubský et al., 2016) sú však učitelia gymnázií nepatrne, hoci štatisticky významne spokojnejší. Táto spokojnost' môže súvisiet' práve s tým, ako bola školská reforma pre gymnáziá zavádzaná - vychádzala z predchádzajúceho projektu, v ktorom sa overovalo vytvorenie vzdelávacích oblastí 
128 a kompetencií. Zároveň, v rámci národného projektu prebehli základné školenia pre vedenia škôl a vybraných učitelov. Spokojnost's reformou môže byt' ovplyvnená aj tým, že riaditelia gymnázií vd’aka Asociácií štátnych gymnázií boli zahrnutí do tvorby východísk štátnych vzdelávacích programov pre tento typ škôl (predbežné výsledky výskumu projektu To dá rozum, 2017). Reforma tak aspoň čiastočne reflektovala ich požiadavky smerujúce ku skvalitneniu všeobecného vzdelávania na gymnáziách. Zosúladenie požiadaviek praxe s ciel'mi vzdelávacej politiky je pre úspešnost' transformačných procesov dôležitým elementom, čo potvrdzujú práce viacerých autorov (Hargreaves, 2005; Ho, 2010; Terhart, 2013).

Aj napriek uvedeným pozitívam reformného procesu $v$ gymnáziách, učitelia aj riaditelia sú nad'alej kritickí $k$ stavu školstva v čase výskumu a nastaveniu spoločnosti k vzdelaniu. Dôvodom skepsy učitel'ov a ich negatívne vnímanie smerovania slovenského školstva môže byt' spôsob, akým sú zmeny v školskom systéme zavádzané: „transformácia vzdelávania na Slovensku sa uskutočňuje cez nereflektovanú prax a rozhodnutia rôznorodých aktérov (aj menších hráčov) vo vzdelávaní a vzdelávacej politike“ (Kaščák \& Pupala, 2012, s. 18). Súčasne, platí, že ak sú potreby učitelov, nerešpektované, implementácia reformných procesov je neúspešná (Porubský, Poliach, Trnka, \& Cachovanová, 2015). Pomenovaný stav je prekážkou v zavádzaní zmien $v$ školách. Avšak, presvedčenie učitelov, že aj napriek negatívam je potrebné $v$ reformách pokračovat', poukazuje na to, že učitelia si uvedomujú, že zmeny $\checkmark$ školstve sú potrebné. Takýto postoj učitelov je pre reformu školského systému vítaný. Pre kurikulárnu politiku je vysoký level zapojenia učitel'ov do rozhodovacích procesov potrebnou podmienkou pre úspech (Ho, 2010).

$\checkmark$ rámci druhého výskumného ciel'a sme sa zamerali na to, aby sme zistili, nakol'ko bolo uskutočnenie reforiem na slovenských gymnáziách potrebné a do akej miery sa na tom podiel'ali špecifické oblasti kurikula. Zásadné zistenia z tejto oblasti sú:

- Okolo 80 \% učitelov považovala reformu dôležitú v oblasti vyššej akceptácie osobitostí žiaka a tiež v podpory pozitívnej klímy $v$ triede.

- Najnaliehavejšie očakávanou zmenou spomedzi hodnotených bola modernizácia učebných metód, stratégií a foriem, želalo si ju až 9 z 10 učitel'ov.

- Decentralizácia moci a tvorba vlastného školského vzdelávacieho programu bola ako naliehavá požiadavka uvádzaná asi dvomi tretinami učitelov gymnázií.

- Niečo menej naliehavé ako predchádzajúce oblasti očakávaných zmien bola oblast' ciel'ov a vzdelávacích výstupov a učiva.

Naliehavost' potreby reformy bola pocit’ovaná vo všetkých skúmaných oblastiach, aj ked' nie rovnako silno. Najsilnejšie bola akcentovaná modernizácia vyučovacích stratégií a podpora pozitívnej klímy v triede. Naproti tomu, významne menej učitelia gymnázií pocit’ovali potrebu zmien $v$ zmysle decentralizácie moci a zmien cielov a obsahov učiva. Trend je opät' zhruba rovnaký u podskupín vedúcich aj učitel'ov, tiež v podskupinách z hl'adiska dížky praxe. V porovnaní s učitel'mi 2. stupňa základnej školy (Porubský et al., 2016) učitelia gymnázií pocit’ovali potrebu zmeny významne silnejšie, aj ked' efekt je stále pomerne slabý. 
Zistenia $v$ tejto oblasti naznačujú typy problémov, ktoré na Slovensku učitelia

gymnázií vo svojej práci pocit'ujú, problémy s vytváraním a udržaním pozitívnej klímy školy, problémy so vzt'ahmi so žiakmi, statickost' metód a foriem výučby, ale aj nedostatočnú individualizáciu výučby. Na druhej strane, učitelia nepocitovali potrebu menit' obsah a ciele vzdelávania. Vzácna zhoda medzi učitel'mi základných škôl (Porubský et al., 2016) a gymnázií je najmä v tom, že vnímajú potrebu zmeny najmä na úrovni individuálnej práce učitel'a v triede, počas výučby, pri práci s konkrétnymi žiakmi. Očakávanie externej podpory pri plánovaní, ale najmä pri riadení vyučovacieho procesu môže do istej miery súvisiet' s didaktickými kompetenciami učitelov. Napriek tomu, že sa na Slovensku nerealizujú komplexné výskumy v oblasti skúmania školskej reality, exitujú indície, ktoré naznačujú, že didaktické kompetencie slovenských učitel'ov nie sú porovnatel'né s učitel'mi z iných krajín (Sonmark et al., 2017). Nízke pedagogické znalosti z oblasti vyučovacieho procesu, ale aj slabé osvojené zručnosti v oblasti diagnostiky, plánovania, riadenia aj evalvácie vyučovacieho procesu (Tomengová et al., 2017) môžu byt' príčinou očakávaní, že externé prostredie vytvorí podmienky na lepšiu prácu učitel'a v triede. Z hl'adiska naplnenia očakávaní učitel'ov gymnázií od školskej reformy však môže tento popísaný stav spôsobit', že žiadna reforma, ktorá sa bude koncentrovat' len na zmenu obsahu a cielov vzdelávania a nepripraví učitelov na spracovanie novej koncepcie, môže spôsobit' opätovný pocit negatívneho prijatia reformy - potvrdzujú sa tak zistenia Terharta (2013) o zlyhávaní reformných snáh. Príčiny vyplývajúce z odpovedí respondentov súvisia so psychodynamickými dôvodmi (nereálne očakávania na školy, najmä z dôvodu slabej pripravenosti učitel'ov, vytvárajú politické prekážky pre uplatnenie použitel'ných vedomostí).

Zmapovat', v ktorých oblastiach učitelia gymnázií pocítili reformu ako prínosnú bolo zámerom tretieho výskumného ciela. Medzi hlavné zistenia zarad'ujeme:

- Z hladiska skvalitnenia výučby učitelia najvyššie prínosy vidia v zavedení modernej koncepcii vzdelávania, možnosti zohl'adňovat' individualitu žiakov a v zlepšení metód a foriem výučby. Len niečo málo viac ako 50 \% učitel’ov uznáva prínosy reformy aj v oblasti vzdelávacích ciel'ov a obsahov. Prakticky v protiklade s uvedeným až dve tretiny učitel'ov nevidí prínos reformy $v$ zmysle zlepšenia vyučovacích výsledkov žiakov.

- Možnost' škôl profilovat' sa v zmysle zohl'adnit' špecifiká školy a potreby žiakov a učitel'ov zarad'ujú učitelia k najsilnejším prínosom reformy (uznávajú ich až tri štvrtiny učitelov). Profilácia v zmysle hlbšieho prepojenia školy s praxou je však vnímaná skôr ambivalentne.

- Skvalitnenie pedagogického riadenia ako prínos reformy hodnotia učitelia vo väčšine položiek (napr. manažovanie práce, klíma školy, pozitívne pedagogické myslenie) najčastejšie mierne negatívne. Výnimku tvorí mierne pozitívnejšie hodnotenie prínosu vo forme zlepšenia spôsobu vedenia vyučovania na škole. Navyše, pri posudzovaní tejto témy sa častejšie objavila neistota signalizovaná vol'bou alternatívy „neviem“. 
- S naplnením ambície zlepšit' reformou vzt’ahy školy so žiakmi a ich rodinami učitelia prevažne mierne nesúhlasia. Platí to najvýraznejšie v oblasti zvýšenia záujmu žiakov o učenie. V oblastiach zlepšenia komunikácie školy s rodinou, pozitívnejších názorov rodičov na školu je negativita hodnotenia miernejšie, ale je sprevádzaná neistotou, (vol'bu „neviem“ vyjadruje až pätina učitel'ov). Pozitívnou výnimkou v zmysle uznania prínosu reformy je iba oblast' aktivity a tvorivosti žiakov. Celkové uznanie prínosov reformy je skôr ambivalentné. Viac prínosov učitelia vidia $v$ oblasti skvalitnenia výučby a $v$ možnosti škôl profilovat' sa. Menej prínosov vidia v skvalitnení pedagogického riadenia a v zlepšení vzt’ahov školy so žiakmi a ich rodinami. Posudzovanie prínosov reformy sa významne nelí̌i medzi podskupinami učitel'ov a vedúcich, ani v podskupinách z hl'adiska rokov praxe. Oproti učitel'om 2. stupňa základnej školy učitelia gymnázií hodnotia prínosy reformy o niečo pozitívnejšie, čo dokladujú aj testy významnosti, aj ked' efekty považujeme len za slabé.

Nerozhodný postoj učitelov gymnázií v oblasti prínosov reformy môže vyplývat' z niekol'kých skutočností: nepripravenost' učitel'ov na zmenu v takom rozsahu (všetky stupne vzdelávania, tvorba učebných osnov, školských vzdelávacích programov, kompetenčný model kurikula) a $v$ takom spôsobe (nepripravenost' učitelov, nevysvetlenie základných východísk reformy, krátkost' času na realizáciu zmien, nekompletnost' štátnych vzdelávacích programov). $V$ podstate sa učitelia so zmenou paradigmy vzdelávania mali vysporiadat' sami, bez odbornej podpory a v priebehu dvoch mesiacov letnej dovolenky. Tento unikátny spôsob zavádzania školskej reformy (Kosová \& Porubský, 2011a) spôsobil negatívne naladenie učitelov. Navyše, na pedagogické riadenie transformačných procesov na úrovni škôl neboli pripravení ako riaditelia. Všetky uvedené aspekty sú v protiklade s popísanými predpokladmi na úspešnú implementáciu školskej reformy (Brundrett \& Duncan, 2011; Fullan, 2007; Ho, 2010; McKenney \& Reeves, 2012).

\subsection{Limity štúdie}

Za hlavné obmedzenie uskutočnenej štúdie považujeme spôsob výberu (dostupný), kde sa do výskumu pravdepodobne zapojili iba motivovanejší respondenti. Napriek tomu faktu je však názorová variabilita badatel'ná v dátach u všetkých premenných pomerne vel'ká a nemáme poznatky o jednoznačnom skreslovaní v pozitívnom alebo negatívnom smere. Výsledky sa navyše vel'mi podobajú výsledkom inej štúdie, založenej na stratifikovanom náhodnom výbere (Porubský et al., 2016).

Diskutovatel'nou témou by mohla byt' aj on-line forma administrácie ako prípadný zdroj skreslenia alebo znekvalitnenia dát. Ako sme však už uviedli vyššie (Callegaro \& Baker, 2014; Vehovar \& Manfreda, 2008; Wladis \& Samuels, 2016), súčasné poznatky vedú skôr k emancipácii on-line administrácie voči jej tradičným formám.

Napokon treba brat' do úvahy aj fakt, že administrácia sa uskutočnila koncom roka 2015 a odvtedy sa názory učitel'ov gymnázií mohli v niečom zmenit'. Súčasne, $\checkmark$ roku 2015 bolo celkové nastavenie učitel'ov ovplyvnené d’alšou inováciou kurikula pre všetky stupne vzdelávania. Inovácia kurikula mala vel'mi podobný priebeh ako 
zavedenie školskej reformy $v$ roku 2008, tzn. v marci schválené štátne vzdelávacie programy vstúpili do platnosti v septembri 2015. V čase realizácie výskumu tak školy dokončievali inovované školské vzdelávacie programy. Zároveň môžu byt' tieto výsledky dobrou poznatkovou základňou pre replikačný výskum.

\subsection{Závery}

V našom výskume sme sa zameriavali na identifikovanie determinantov ovplyvňujúcich implementáciu kurikulárnej reformy z pohladu gymnaziálnych učitelov. Východiskom pre dosiahnutie ciela bolo vytvorenie a distribúcia upraveného on-line dotazníka vlastnej konštrukcie IKR-2014.

Výsledky survey $v$ uvedených oblastiach (index spokojnosti, index naliehavosti, index prínosu) poukázali na to, že učitelia paradoxne od školskej reformy očakávali skôr zmeny na úrovni ich vlastných učitel'ských kompetencií: modernizácia metód, foriem, výučbových stratégií, zlepšenie vzt’ahu so žiakmi. To, čo reálne vyžaduje štátnu reguláciu (vzdelávacie výstupy a ciele, vzdelávacie obsahy a pod.), učitelia označovali ako potrebné, avšak len mierne. Očakávania učitelov základných škôl a gymnázií od kurikulárnej reformy odhal'ujú teda aj d’alší problém - kvalitu prípravy a d'alšieho vzdelávania učitel'ov na Slovensku. Učitelia pocit'ujú neistotu v základných pedagogických spôsobilostiach: formulácia cielov výučby, výber a využívanie metód a foriem výučby $v$ závislostí od individuálnych potrieb žiaka, komunikácia so žiakom a jeho rodinou. Podobné výsledky v oblasti pedagogických spôsobilostí učitelov, ale $v$ inom kontexte, priniesol aj medzinárodný pilotný projekt overujúci úroveň profesijných kompetencií učitelov (Sonmark et al., 2017; Tomengová et al., 2017). Tieto zistenia naznačujú nekompatibilitu prípravy učitelov a požadovaných profesijných kompetencií učitelov a pripomínajú potrebu systematického riadenia vzdelávacej politiky.

Výsledky survey tiež podporujú názor, že prijatie reformy (pozitívne alebo negatívne) je v konečnom dôsledku závislé od naladenia, postojov a názorov učitel'ov na transformačné procesy a implementáciu zmien. Pre následné reformy je teda nevyhnutné spolupracovat' s učitel'mi, aktívne ich zapájat' do procesov zmien, spoločne s nimi vytvárat' metodické materiály a súčasne iniciovat' zmeny v oblasti profesijného rozvoja učitelov v súlade s očakávanými zmenami. Všetky uvedené kroky smerujú nielen k zosobneniu reformy, ale aj k vývoju a overovaniu inovatívnych metód a stratégií výučby a v konečnom dôsledku k pozitívnym zmenám aj vo vzdelávacích výsledkoch žiakov.

\section{Literatúra}

Beck, U. (2011). Riziková společnost. Na cestě k jiné moderně. Praha: SLON.

Blasius, J., \& Brandt, M. (2010). Representativeness in online surveys through stratified samples. Bulletin de Méthodolgie Sociologique, 107, 5-21. 
132 Brundrett, M., Duncan, D., \& Rhodes, C. (2010). Leading curriculum innovation in primary schools project: An interim report on school leaders' roles in curriculum development in England. Education 3-13. International Journal of Primary, Elementary and Early Years Education, 38(4), 403-419.

Callegaro, M., Baker, R. P., Bethlehem, J., Göritz, A. S., Krosnick, J. A., \& Lavrakas, P. J. (2014). Online panel research. A data quality perspective. Chichester: John Wiley \& Sons.

Connelly, F. M., \& Clandinin, D. J. (1988). Teachers as curriculum planners. New York: Teachers College Press.

Dodou, D., \& de Winter, J.C.F (2014). Social desirability is the same in offline, online, and paper surveys: A meta-analysis. Computers in Human Behavior, 36, 487-495.

European Commission (2017). Education and training. Monitor 2017. Luxembourg: Publications Office of the European Union. Dostupné z https://ec.europa.eu/education/policy /strategic-framework/et-monitor_en

Fullan, M. (2007). The new meaning of education change. New York: Teacher College Press.

Hargreaves, A. (2005). Educational changes takes ages: Life, career and generational factors in teachers' emotional responses to educational change. Teaching and Teacher Education, 21(8), 967-983.

Ho, D. Ch. W. (2010). Teacher participation in curriculum and pedagogical decisions: Insights into curriculum leadership. Educational Management Administration Leadership, 38(5), 613-624.

Kaščák, O., \& Pupala, B. (2012). Škola zlatých golierov. Vzdelávanie v ére neoliberalizmu. Praha: SLON.

Keller, J., \& Tvrdý, L. (2008). Vzdělanostní společnost. Chrám, výtah a pojišt’ovna. Praha: Slon.

Kosová, B., \& Porubský, Š. (2011a). Transformačné premeny slovenského školstva po roku 1989. Banská Bystrica: Pedagogická fakulta UMB.

Kosová, B., \& Porubský, Š. (2011b). The development and transformation of the school system in the Slovak republic after the fall of the totalitarian regime form the aspects of educational policy, educational practice at the level of primary school and university preparation of teachers. The New Educational Review, 23(1), 19-34.

Kríž, M. (2008) Niekol'ko postrehov k prebiehajúcej kurikulárnej transformácii. In Z. Humajová, M. Kríž, B, Pupala, \& P. Zajac, Vzdelávanie pre život. Reforma školstva $v$ súvislostiach (s. 49-54). Bratislava: Konzervatívny inštitút M. R. Štefánika. Dostupné z http://www .noveskolstvo.sk/upload/pdf/Publikacia_Reforma_skolstva_v_suvislostiach.pdf

Liptáková, J. (2017). Shortage of qualified labour hits Slovakia. Spectator. Dostupné z https:// spectator.sme.sk/c/20470071/shortage-of-qualified-labour-hits-slovakia.html

McKenney, S., \& Reeves, T. C. (2012). Educational design research. In J. M. Spector, M. D. Merrill, J. Elen, \& M. J. Bishop, Handbook of research on educational communications and technology (s. 131-140). New York: Springer. Dostupné z https://link.springer.com /content/pdf/10.1007\%2F978-1-4614-3185-5_11.pdf

MŠVVaŠ SR. (1994). Projekt Konštantín. Bratislava: MŠVVaŠ SR. Dostupné z http://www .noveskolstvo.sk/article.php?80

MŠVVaŠ SR. (2013). Správa o stave školstva na Slovensku a o systémových krokoch na podporu jeho d'alšieho rozvoja. Bratislava: MŠVVaŠ SR. Dostupné z https://www.minedu.sk/data /att/5250.pdf

MŠVVaŠ SR. (2015). Rámcový učebný plán pre gymnáziá s vyučovacím jazykom slovenským štvorročný vzdelávací program. Bratislava: MŠVVaŠ SR. Dostupné z http://www.statpedu.sk/files/articles/dokumenty/inovovany-statny-vzdelavaci-program/rup_g_4_r_s_vyuc _jaz_slov.pdf

MŠVVaŠ SR. (2017). Učiace sa Slovensko. Národný program rozvoja výchovy a vzdelávania. Dostupné z https://www.minedu.sk/data/files/6987_uciace_sa_slovensko.pdf

Pavlov, I. (2013). Štandardizácia profesijných kompetencií učitelóov (východiská a perspektívy). Prešov: Škola plus s.r.o. 
Poliach, V. (2015). Exploračný potenciál dotazníka IKR-2014. In Š. Porubský, Ch. Wolhuter, B. Kosová, E. Walterová, T. Janík, V. Mužík ... A. Petrasová, Premeny školského kurikula (slovenská a česká skúsenost') (s. 112-130). Banská Bystrica: Belianum.

Poliach, V. (2016). Výskumný dotazník IKR-2014 z perspektívy získaných dát. Banská Bystrica: Belianum.

Porubský, Š., Kosová, B., Doušková, A., Trnka, M., Poliach, V., Fridrichová, P., Adamcová, E., ... Simanová, L. (2014). Škola a kurikulum - transformácia v slovenskom kontexte. Banská Bystrica: Belianum.

Porubský, Š., Kosová, B., Doušková, A., Trnka, M., Poliach, V., Fridrichová, P., Adamcová, E., ... Simanová, L. (2016). Kurikulum základnej školy očami učitelov (empirické zistenia). Banská Bystrica: Belianum.

Porubský, Š., Trnka, M., Poliach, V., \& Cachovanová, R. (2015). Curricular reform in Slovakia regarding the attitudes of basic school teachers. Pedagogická orientace, 25(6), 777-797.

Revelle, W., \& Zinbarg, R.E. (2009). Coefficients Alpha, Beta, Omega, and the GLB: Comments on Sijtsma. Psychometrika, 74(1), 145-154.

Rosa, V., Turek, I., \& Zelina, M. (2001). Milénium. Národný program výchovy a vzdelávania $\checkmark$ Slovenskej republike na najbližšich 10-15 rokov. Bratislava: IRIS.

Rychen D.S. \& Salganik L.H. (Eds.) (2003). Key competencies for a successful life and a well-functioning society. Göttingen: Hogrefe \& Huber Publishers.

Sonmark, K., Révai, N., Gottschalk, F., Deligiannidi, K., \& Burns, T. (2017). Understanding teachers' pedagogical knowledge: Report on an international pilot study. OECD Education Working Paper No. 159. Paris: OECD Publishing. Dostupné z http://dx.doi .org/10.1787/43332ebd-en

ŠPú. (2006). Rámcový vzdelávací program. Bratislava: ŠPú.

ŠPÚ. (2007). Výročná správa ŠPú. Bratislava: ŠPú. Dostupné z https://www.minedu.sk/data /att/153.pdf

MŠVVaŠ SR. (2013). Ciel'ové požiadavky platné od školského roka 2013/2014. Bratislava: ŠPú. Dostupné z http: / / www.statpedu.sk/sk/maturitne-skusky/platne-od-sk-r-2013/2014/

Terhart, E. (2013). Teacher resistance against school reform: reflecting an inconvenient truth. School Leadership \& Managment, 3(5), 486-600. Dostupné z https://doi.org/10.1080/13 632434.2013.793494

To dá rozum. (2017). Výstupy z predbežnej analýzy rozhovorov s rôznymi aktérmi vo vzdelávaní, realizované v rámci kvalitatívneho výskumu problémov slovenského školstva spracované $\checkmark$ rámci projektu To dá rozum (nepublikovaný materiál).

Tomengová, A., Kosová, B., Poliach, V., Pavlov, I., Šukolová, D., Fridrichová, P., Guffová, D. ... Haviar, M. (2017). Pedagogické znalosti a profesionalita učitel'a. Banská Bystrica: Belianum.

Turek, I. (1993). Duch školy. Pedagogika, 43(2), 121-132. Dostupné z http://pages.pedf.cuni .cz/pedagogika/?attachment_id=3428\&edmc $=3428$

Valica, M., Fridrichová, P., Kaliský, J., Rohn, T., Hajnalová Buvalová, L., \& Bradová, G. (2011). Modely výučby etickej výchovy a kompetenčného profilu učitel'ov etickej výchovy. Banská Bystrica: PF UMB

Vančíková, K. (2018). Čo očakáva pracovný trh od absolventov stredných odborných škôl? Bratislava: SME. Dostupné z https://dennikn.sk/blog/1151585/co-ocakava-pracovny-trh-od -absolventov-strednych-odbornych-skol/

Vehovar, V., \& Manfreda, K.L. (2008). Overview: Online surveys. In N. Fielding, R.M. Lee, \& G. Blank (Eds.), The SAGE handbook of online research methods (s. 177-196). Los Angeles, London: SAGE Publications.

Walterová, E. (2004). Úloha školy v rozvoji vzdělanosti. Brno: Paido, 2004.

Wladis, C., \& Samuels, J. (2016). Do online readiness surveys do what they claim? Validity, reliability, and subsequent student enrollment decisions. Computers \& Education, 98, 39-56. 
134 World Economic Forum (2016). The future of jobs. Employment, skills and workforce strategy for the fourth industrial revolution. Geneva: WEF. Dostupné z http: / / www3. weforum.org /docs/WEF_Future_of_Jobs.pdf

Zákon č. 245/2008 Z. z. o výchove a vzdelávaní (školský zákon) a o zmene a doplnení niektorých zákonov (2008).

Mgr. Petra Fridrichová, PhD., Centrum edukačného výskumu Pedagogická fakulta, Univerzita Mateja Bela Ružová 13, 97411 Banská Bystrica petra.fridrichova@umb.sk

Mgr. Vladimír Poliach, PhD., Katedra psychológie Pedagogická fakulta, Univerzita Mateja Bela

Ružová 13, 97411 Banská Bystrica vladimir.poliach@umb.sk 